\title{
Inorganic Phosphate Uptake in a Brackish Tropical Lagoon
}

\author{
Lionel Lemasson ${ }^{a}$, Jean Pagès ${ }^{a}$ and \\ Jean-Louis Cremoux \\ ORSTOM, Centre de Recherches Océanographiques, Abidjan, Ivory Coast \\ Received 6 August 1979 and in revised form 14 March 1980
}

\begin{abstract}
Keywords: phosphates; light; tropical; brackish waters; lagoon; Ivory coast
In the brackish tropical water of the Ebrié lagoon (Ivory Coast), the influence of the incident light upon the $\mathrm{PO}$ uptake is variable, and depends on the depletion of dissolved inorganic phosphate; this uptake also seems related to the ATP concentration in the seston. So luxury uptake may be observed, which causes imbalance in the elementary composition of the phytoplankton and in the uptake ratios. In P-depleted zones, the photosynthetic C uptake is much more active than the $\mathrm{P}$ uptake, giving $\mathrm{C} / \mathrm{P}$ ratios higher than $300 / \mathrm{x}$.
\end{abstract}

\section{Introduction}

- Dissolved reactive phosphorus, generally ranked with dissolved inorganic phosphorus, is taken up by the aquatic microorganisms (phytoplankton and bacteria) at a rate which depends on the environmental conditions: nutrient concentration, temperature etc. Healey (r973) and Stross \& Pemrick ( 1974 ) observed that $\mathrm{P}$ uptake was stimulated by light but did not follow the photosynthetic carbonate uptake. On the contrary, Mackereth (r953) showed that light and dark assimilation were equal for Asterionella formosa; similarly, Perry (1976) did not observe any difference either between light and dark incubations or between incubations carried out at different light levels for oligotrophic waters in the Central North Pacific. A $24 \mathrm{~h}$ rhythm in the phosphorus uptake rates has been observed by Eppley et al. (197I) on enriched cultures of coastal species, and by Stross and Pemrick (1974) on Lake George phytoplankton. Healey (I973) suggested that this light stimulation only occurs under unrealistically high phosphate concentrations. This problem of phosphate uptake has been studied by us in a tropical brackish environment, with a relatively high temperature $(25$ to $30{ }^{\circ} \mathrm{C}$ ) the year round and a high microbial biomass which accelerates the biochemical processes. The aim of the present paper is the study of phosphate uptake by natural populations as influenced by light in very varied waters.

\section{Description of the area}

The Ebrié lagoon is situated in Ivory Coast, West Africa (Figure I); it extends over more than $150 \mathrm{~km}$, with an area of about $550 \mathrm{~km}^{2}$. Parallel to the coast, it is relatively narrow (maximum width $5 \mathrm{~km}$ ) and generally shallow (inean depth $3 \mathrm{~m}$, with localized spots of

$$
{ }^{a} \text { Present address: Antenne ORSTOM, Station INRA, Avenue de Corzent, }
$$
74203 Thonon, France.

$0302-3524 / 80 / \times 10547+15 \$ 02.00 / 0$

(C) x980 Academic Press Inc. (London) Ltd. 
$5 \mathrm{~m}$ depth). Communication with the sea is through the mouth of the Comoe river, which is narrow and often obstructed, and through the Vridi canal in front of Abidjan. The city of Abidjan, which has more than one million inhabitants, discharges most of its sewage into the lagoon.

The chemical composition of the water and the taxonomical composition of the zoo- and phytoplankton populations are variable, owing to several factors:

alternation of two dry and two wet seasons;

influence of the sea, since the ebb propagates through the Vridi canal toward both eastern and western ends of the lagoon;

freshwater inflow from sometimes polluted streams and during the important flood of the Comoé river;

domestic and industrial sewage in the estuary region around Abidjan.

The physical and chemical environment of the Ebrié lagoon has been described by Tastet (r974), Varlet (1978) and Pagès et al. (1979). U using previous observations from I975 we have divided the Ebrié lagoon into six parts, each of them being characterized by one or two representative stations (Table I). The present study is based on the observations made during the 1977 main dry season (particularly in January and February). This period is characterized by a high insolation with a somewhat shorter daylength ( $\mathrm{I} \times 5 \mathrm{~h}$ ) than during summer; the rains are very scarce and the water temperature high (more than $3 \mathrm{I}^{\circ} \mathrm{C}$ at Stations A and K) (Varlet, 1978).

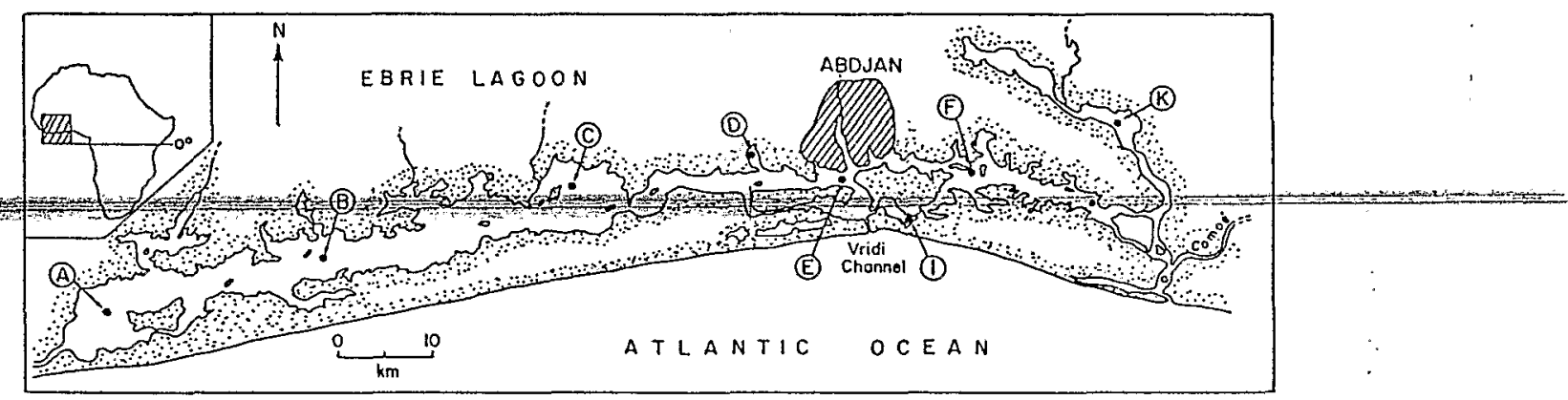

Figure r. Location of stations in the Ebrie lagoon (Ivory Coast); letters indicate sampling sites.

\section{Methods}

(1) Physico-chemical data (Table 2)

Several environmental parameters were measured either simultaneously with incubations sampling, or at other times during the day:

salinity, temperature, transparency (Secchi disk), light, oxygen;

on water filtered through a $200 \mu \mathrm{m}$ gauze: particulate phosphorus $(\mathrm{PP})$, nitrogen $(\mathrm{NP})$ and carbon (CP), chlorophyll $a$ (chl a), ATP, primary production (by ${ }^{14} \mathrm{C}$ and $\mathrm{O}_{2}$ methods), and phosphate uptake;

on water filtered through a Gelman fibreglass filter: $\mathrm{PO}_{4}-\mathrm{P}$ and dissolved organic phosphorus, $\mathrm{NO}_{3}-\mathrm{N}, \mathrm{NO}_{2}-\mathrm{N}, \mathrm{NH}_{4}-\mathrm{N}$ and dissolved organic nitrogen, dissolved organic carbon. These parameters were measured by standard methods (Strickland \& Parsons, Ig68; Holm-Hansen \& Booth, I966). 
TABLE I. Main characteristics of the sampling stations in the Ebrié lagoon

\begin{tabular}{|c|c|c|}
\hline Stations & Date & Main characteristics \\
\hline A & II Jan 1977 & $\begin{array}{l}\text { Brackish; no tidal influence; } S \%=4 . \text { Shallow; high } \\
\text { productivity; } P \mathrm{P}_{4}-\mathrm{P} \text { depleted. }\end{array}$ \\
\hline $\begin{array}{ll}B & \text { (a) } \\
& \text { (b) }\end{array}$ & $\begin{array}{l}\text { I Feb } 1977 \\
4 \text { May } x 977\end{array}$ & $\begin{array}{l}\text { Brackish; no marine influence. } S \%=2 \text { to } 4 \text {. Deep; } \\
\text { high productivity. Limiting factor: N. }\end{array}$ \\
\hline C & $\times 5 \mathrm{Feb} 1977$ & $\begin{array}{l}\text { Slight influence of the sea; near the mouth of a river; } \\
S \%=4 \text { to } 7 . \text { Nutrient depleted. }\end{array}$ \\
\hline $\mathrm{D}$ & 22 Feb 1977 & $\begin{array}{l}\text { Bight with narrow mouth. Marine influence. Shallow. } \\
S \%=12 \text { to } 25 .\end{array}$ \\
\hline $\mathbf{E}$ & r8 Jan 1977 & $\begin{array}{l}\text { Deep estuarine zone. High influence of the sea. } \\
\mathrm{N} \text { depleted. } S \%=24 \text { to } 30 \text {. }\end{array}$ \\
\hline $\mathrm{F}$ & $8 \mathrm{Feb}$ I977 & $\begin{array}{l}\text { Estuarine zone, deep. High influence of the sea. } \\
N \text { depleted. } S \%=r_{5} \text { to } 18 \text {. }\end{array}$ \\
\hline $\begin{array}{ll}\text { I } & \text { (a) } \\
\text { (b) } \\
\text { (c) } \\
\text { (d) }\end{array}$ & $\begin{array}{l}23 \text { Jul } \times 976 \\
6 \text { Aug } 1976 \\
4 \text { Jan } \times 977 \\
4 \text { Nov } x 976\end{array}$ & $\begin{array}{l}\text { Bight nearly closed, very polluted; urban zone. } \\
\text { Eutrophication. Tidal influence. } S \%=20 \text { to } 22 \text {. }\end{array}$ \\
\hline $\mathbf{K}$ & $25 \mathrm{Jan} 1977$ & $\begin{array}{l}\text { Bight nearly closed; marine influence. Shallow. } \\
\text { Important freshwater inflows (proximity of two } \\
\text { rivers: Mé and Comoé); } S \%=0 \text {. }\end{array}$ \\
\hline
\end{tabular}

TABLI 2. Chemical and biological parameters at each station. $\mathrm{PO}_{4}-\mathrm{P}, \mathrm{NO}_{3}-\mathrm{N}$, $\mathrm{NH}_{4}-\mathrm{N}, \mathrm{C}_{\mathrm{p}}, \mathrm{N}_{\mathrm{p}}, \mathrm{P}_{\mathrm{p}}$ : daily average values in $\mu \mathrm{mol}^{-1}, \mathrm{~N}_{1}, \mathrm{P}_{\mathrm{l}}$ : inorganic dissolved $N$ and $P$; chl $a, A T P$ : in $\mu \mathrm{g}^{-1} ; \Delta \mathrm{C} / \Delta \mathrm{P}$ : assimilation ratio; $\mathrm{P}$ uptake: $\mathrm{PO}, \mathrm{A}$ taken up during $24 \mathrm{~h}$ ( $\mu$ mol $1^{-1}$ )

\begin{tabular}{|c|c|c|c|c|c|c|c|}
\hline Station & $\mathrm{PO}_{4}-\mathrm{P}$ & $\begin{array}{c}\mathrm{NO}_{3}-\mathrm{N}+ \\
\mathrm{NH}_{4}-\mathrm{N}\end{array}$ & $N_{1} / P_{1}$ & ${ }_{1} C_{p} / N_{p}$ & $C_{p} / P_{p}$ & $\Delta \mathrm{C} / \Delta \mathrm{P}$ & $\mathrm{C}_{\mathrm{p}} / \mathrm{chl} a$ \\
\hline A & $0 \cdot 14$ & $x \cdot 60$ & $x I \cdot 9$ & 10.5 & $3 \times 2$ & 549 & $2 \mathrm{II}$ \\
\hline B (a) & 0.40 & $I \cdot 06$ & $2 \cdot 7$ & $10 \%$ & × 78 & 270 & 169 \\
\hline C & 0.17 & 0.84 & $4 \cdot 9$ & $I I \cdot I$ & II 2 & $6 \mathrm{I}$ & 190 \\
\hline D & 0.13 & 0.54 & $4 \cdot 2$ & 10.8 & 129 & 26 & 158 \\
\hline$E$ & 0.64 & $x \cdot 73$ & $2 \cdot 7$ & $7 \cdot 2$ & $9 \mathrm{I}$ & 27 & ro3 \\
\hline $\mathrm{F}$ & $0.5 \mathrm{I}$ & 0.92 & $x \cdot 8$ & $8 \cdot 8$ & 87 & 97 & II 5 \\
\hline $\mathrm{K}$ & 0.79 & $5 \cdot 37$ & $6 \cdot 8$ & $7 \cdot 8$ & 197 & 36 & 162 \\
\hline I (c) & $2 \cdot 7 x$ & $30 \cdot 70$ & $11 \cdot 3$ & $7 \cdot I$ & 74 & 38 & 103 \\
\hline I (a) & $2 \cdot 57$ & 一 & 一 & $4 \cdot 8$ & $5^{2}$ & - & 一 \\
\hline \multirow[b]{2}{*}{ Station } & \multirow[b]{2}{*}{$\mathrm{C}_{\mathrm{p}} / \mathrm{ATP}$} & \multirow{2}{*}{$\frac{P \text { uptake }}{\text { ATP }}$} & \multirow{2}{*}{$\frac{\text { P uptake }}{P_{p}}$} & \multirow{2}{*}{$\frac{\text { P uptake }}{\operatorname{chl} a}$} & \multirow[b]{2}{*}{ P uptake } & \multirow{2}{*}{$\begin{array}{l}\text { P uptake } \\
\text { min. }\end{array}$} & \\
\hline & & & & & & & $\max$. \\
\hline A & x7343 & I 77 & 0.41 & 0.022 & $0.5^{6} 5$ & 0.007 & 0.035 \\
\hline B (a) & 1437 & 0.23 & 0.31 & 0.026 & 0.370 & 0.008 & 0.026 \\
\hline C & 1316 & $0.5^{8}$ & 0.48 & 0.085 & 0.410 & 0.014 & 0.032 \\
\hline $\mathrm{D}$ & 513 & 0.45 & $x=19$ & 0.112 & $1 \cdot 522$ & 0.029 & 0.058 \\
\hline $\mathrm{E}$ & 834 & $2 \cdot 2 I$ & 3.03 & 0.283 & $2 \cdot 970$ & 0.083 & 0.057 \\
\hline $\mathrm{F}$ & 479 & 0.32 & 0.64 & 0.064 & 0.414 & 0.015 & 0.076 \\
\hline $\mathrm{K}$ & $I_{4} 61$ & $I \cdot 10$ & 1.87 & $0.1 \pm 6$ & $r \cdot 262$ & 0.054 & 0.253 \\
\hline I (c) & 847 & $I \cdot I 5$ & $1 \cdot 49$ & 0.155 & $2 \cdot 617$ & 0.026 & 0.090 \\
\hline I (a) & 1620 & $I \cdot 13$ & - & - & $x \cdot 69$ & $\begin{array}{c}0.003 \\
d\end{array}$ & $\begin{array}{c}0.040 \\
l\end{array}$ \\
\hline
\end{tabular}


(2) Light measurements

The light intensity at incubation depth was measured at noon with a photoelectrical cell (Charlottenlund) with green filter. When no in situ measurements were available, light intensity $I_{z}$ at depth $z$ (in $\mathrm{m}$ ) was calculated from the surface intensity $I_{0}$ and Secchi disk reading $z_{s}$ (in $\mathrm{m}$ ) by the classical relationship

$$
\ln I_{z}-\ln I_{0}=-\varepsilon . z
$$

$\varepsilon$ being determined from $z_{3}$ by the empirical formula (Pagès et al., r980):

$$
\frac{I}{\varepsilon}=0.449 \cdot z_{s}-0.054
$$

(3) Primary productivity

Photosynthesis was evaluated by the $\mathrm{O}_{2}$ method and the ${ }^{14} \mathrm{C}$ method. For the latter, the determination of the total $\mathrm{CO}_{2}$ was necessary at each station, as the carbonate concentration is a function of the freshwater-seawater ratio, which varies from a few per cent (Station A) to $100 \%$ (estuarine zone, Station E).

\section{(4) ${ }^{32} \mathrm{P}-\mathrm{PO}_{4}$ tracer experiments}

The tracer was carrier-free ${ }^{32} \mathrm{PO}_{4} \mathrm{Na}_{2} \mathrm{H}$ (Commissariat à l'Energie Atomique, France) dissolved in water, with an initial activity of $2 \mathrm{mCi} \mathrm{ml}^{-1}$. The samples were first filtered through a $200 \mu \mathrm{m}$ mesh net, and incubated in $65 \mathrm{ml}$ bottles after introduction of $200 \mu \mathrm{l}$ of tracer solution, giving activities of 0.2 to $20 \times 10^{6} \mathrm{dpm}$ per sample variable with the experiment.

The incubations were carried out in duplicate or triplicate in the light and in the dark, generally with controls sterilized by formalin (final concentrations $0.46 \%$ ) or $\mathrm{HgCl}_{2}$ (final concentration $0.4 \mathrm{~mm}$ ). During the 'continuous' incubations, several identical samples were inoculated simultaneously and incubated during various periods, up to $6 \mathrm{~h}$. During the 'stepwise' incubations, several samples were taken simultaneously and incubated under the same conditions. At 2 -h intervals, radioactive tracer was added to duplicates or triplicates which were then incubated for an extra period of $\mathrm{I}-2 \mathrm{~h}$ before filtration. In the so called 'vertical' incubations, samples of surface water were incubated at various depths after introduction of the tracer.

The samples were filtered on Gelman glass-fibre filters under roo torr depression. The counting was made with a liquid scintillation counter working on the whole spectrum by using the Cerenkov radiation (Kobayashi \& Maudsley, 1974).

\section{Kinetics}

The phosphate uptake kinetics were studied by enriching $65 \mathrm{ml}$ samples with a solution of $\mathrm{KH}_{2} \mathrm{PO}_{4}$ giving concentrations of 0.1 to $50 \mu \mathrm{mol} \mathrm{I}^{-1}$ of added substrate. The half-saturation constant $\left(K_{\mathrm{s}}\right)$ and maximum uptake rate $\left(V_{\mathrm{m}}\right)$ were measured at each station from day experiments and from night ones. They were determined by Woolf plot:

$$
\frac{S}{V}=\frac{S}{V_{\mathrm{m}}}+\frac{K_{\mathrm{s}}}{V_{\mathrm{m}}}
$$

and calculated with respective standard deviations by the Wilkinson (196I) method. 


\section{Results}

For brevity the following abbreviations are used: $l$, uptake for uptake in the light; $d$, uptake for uptake in the dark; $(l-d)$, uptake for $l$-uptake minus $d$-uptake.

\section{Time course of the uptake}

(a) Adsorption. A very rapid adsorption of ${ }^{32} \mathrm{P}$ takes place during the first minutes of an incubation, and has been evaluated in two ways:

(i) by incubating inoculated samples during various times between $I$ and $30 \mathrm{~min}$, and stopping the incubation by filtration [Station I, figure 2 (b)]; extrapolating the curve back to zero time gives a good approximation of the adsorption on the seston and of the filter blank.

Thus we can see that the adsorption takes place during the first $3 \mathrm{~min}$, with no further rise of this adsorption activity during the incubation. This will be discussed later, but it clearly implies a purely physical exchange between water and suspended particles (Taft et al., I975).
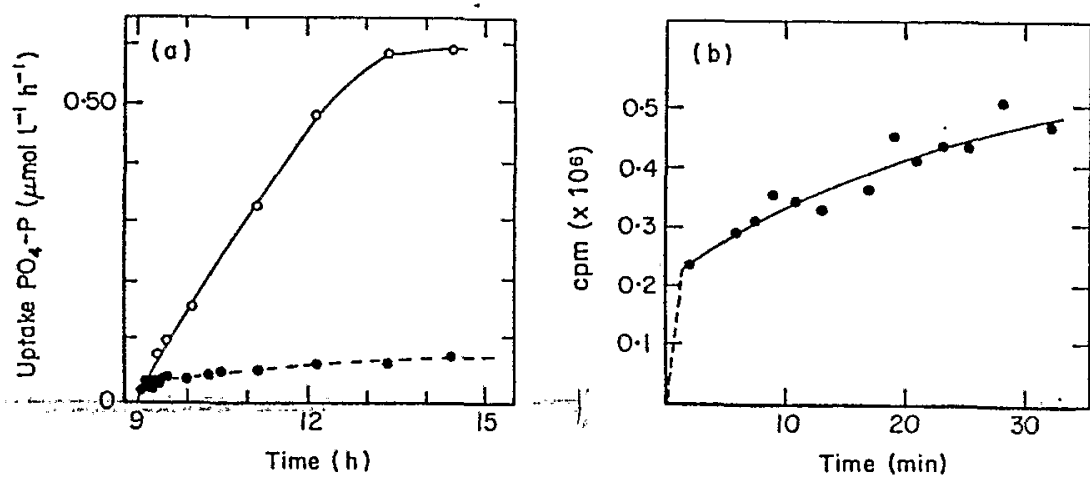

Figure 2. Phosphate uptake at Station I on 23 July 1977. (a) PO $-\mathrm{P}$ uptake in the light (open circles, each representing the mean value of three samples) and in the dark (solid circles, each corresponding to the mean value of two samples), vs. local time. (b) ${ }^{3} \mathrm{PO}, d$ uptake $v s$. time, showing rapid adsorption in the first $3 \mathrm{~min}$ Each point corresponds to one sample.

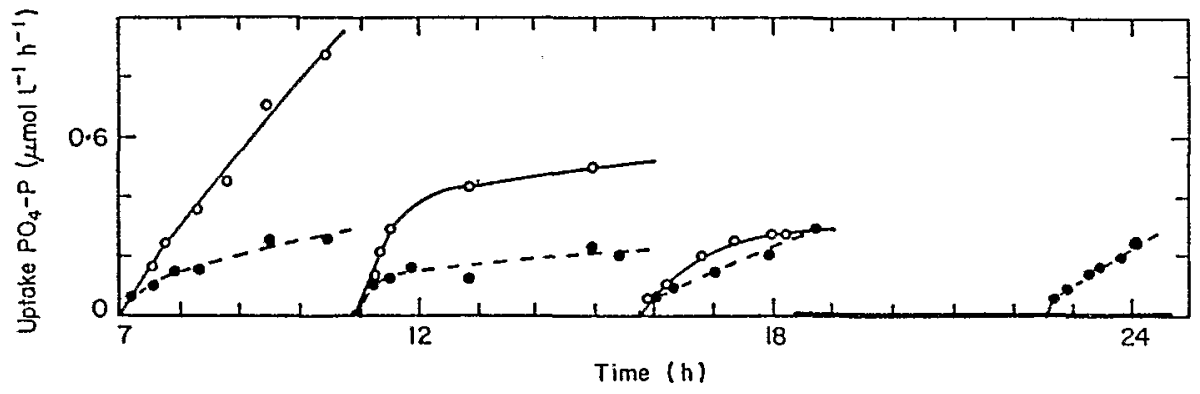

Figure 3. Phosphate uptake at Station $\mathrm{C}$ in the light (open circles) and in the dark (solid circles) vs. time ('stepwise' incubation); each point corresponds to one sample. The type of the uptake curves is varying during the day from mono- to biphasic. The effect of light decreases during the day. 

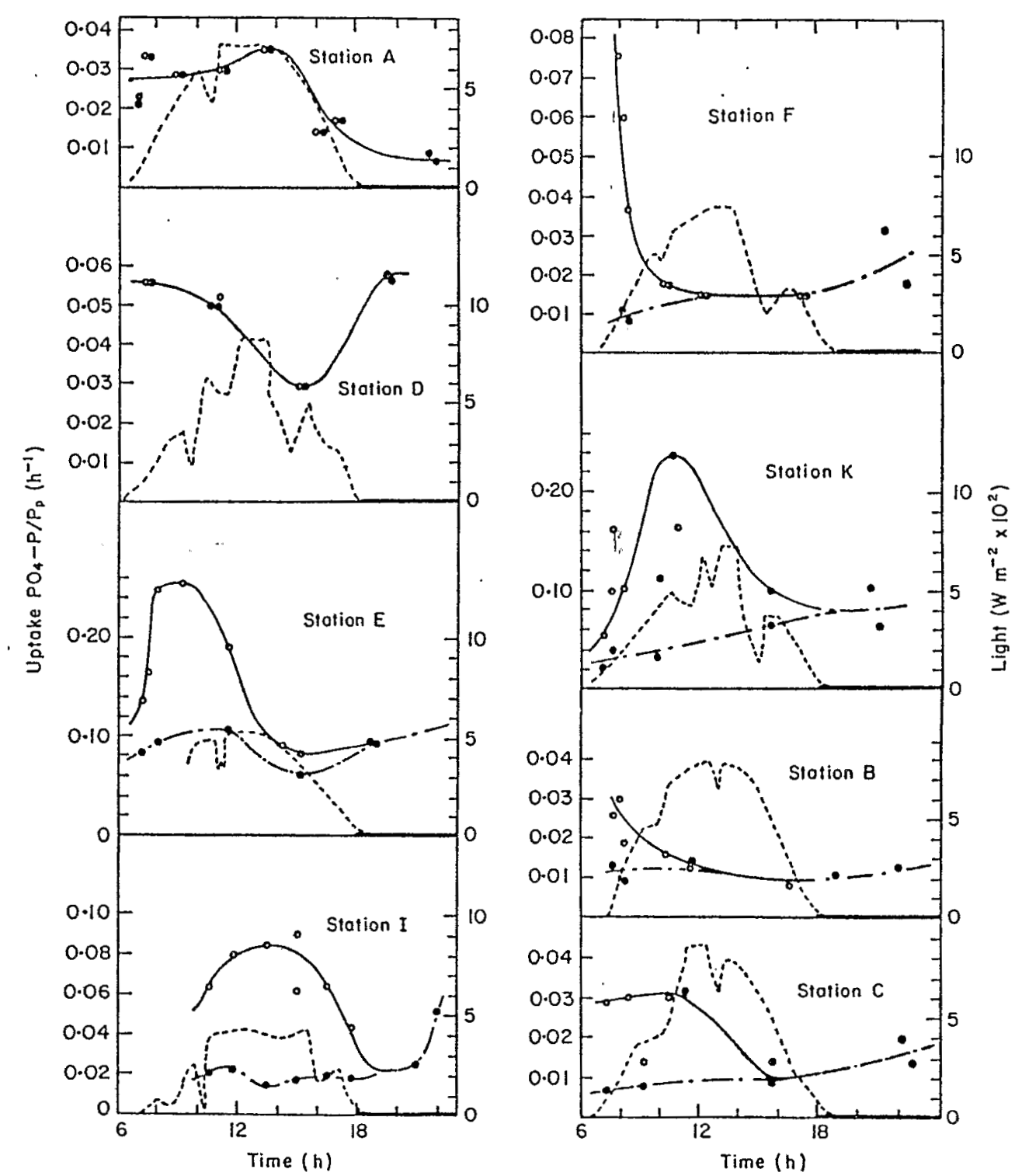

Figure 4. $\mathrm{PO}_{\mathrm{d}}-\mathrm{P}$ uptake rates relative to $\mathrm{P}_{\mathrm{p}}$ in the light (open circles, solid line and in the dark (solid circles, dashed line) and incident light (dotted line) vs. local time, for some stations. The uptake rates are corrected for adsorption and evaluated from the $\mathrm{PO}_{1}-\mathrm{P}$ concentrations at sampling time. Units: uptake rate in $\mathrm{h}^{-1}$ $\left(\mu \mathrm{mol} \mathrm{l^{-1 }} \mathrm{h}^{-1} \mathrm{PO}_{4}-\mathrm{P} / \mu \mathrm{mol} \mathrm{I}^{-1} \mathrm{P}_{\mathrm{p}}\right)$; time in $\mathrm{h}$; light in $\mathrm{W} \mathrm{m}^{-2}$.

(ii) by adding formalin to samples, and incubating them along with the living samples.

The adsorption, calculated from 93 formalin controls, is $1 \cdot 72 \pm 0.27 \%$ of the inoculated activity.

(b) Uptake. The uptakes, as expressed in $\mu \mathrm{mol} 1^{-1}$ of $\mathrm{PO}_{4} \mathrm{P}$ per $24 \mathrm{~h}$, are compared in Table 2 to some biomass parameters (ATP, chl $a$ and $\mathrm{P}_{\mathrm{p}}$ ). As intracellular ATP level is variable with the state of depletion of a population, we have used $P_{p}$ and chl $a$ as evaluation 
of the biomass. Owing to its rapid remineralisation in tropical waters (Lemasson et al., ${ } 980), P_{D}$ is a good measure of the seston biomass; the ratio of the $P$ uptake rate to $P_{p}$ (in $\mathrm{h}^{-1}$ ) gives an indication of the turnover rate of the cellular phosphorus.

We observed two main types (mono-and biphasic) of time-course of uptake. The biphasic type shows a first phase, possibly including the adsorption processes, with a high uptake rate, and a second phase with a slower uptake as has been observed by several authors (Lcan, I973; Taft et al., 1975). The relative importance of the first phase is variable, an extreme value being found at Station $A$ where $78 \%$ of the total uptake occurred in the first hour, probably with an important rôle of the adsorption processes, whereas adsorption of killed samples was on an average $3.6 \%$ of the total uptake.

The other type is monophasic, with a nearly constant uptake rate [Figure 2(a)]. Intermediate types show an initial high uptake rate, slowly declining during the incubation.

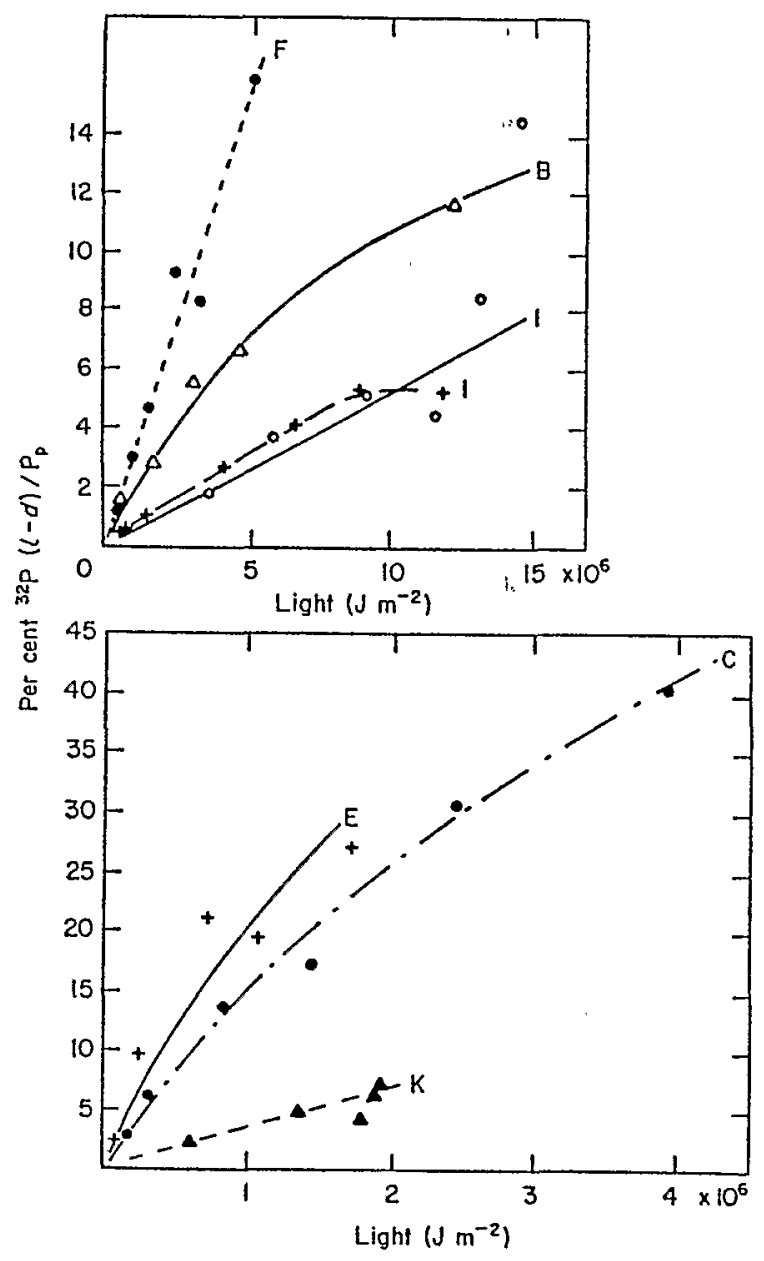

Figure 5. ${ }^{32} \mathrm{P}-\mathrm{PO}$, uptake $(l-d)$.in per cent of initial activity, $v$ s total incident light received for 'stepwise' incubations of surface water samples; light energy is integrated on the duration of the experiment. Symbols (with in situ PO $-\mathrm{P}$ concentration in $\left.\mu \mathrm{mol} \mathrm{l}^{-1}\right)$ (O) Station I (d) $(0.4 \mathrm{I}) ;+$, Station I (a) $(2.57) ; \Delta$, Station B (a) $(0.48)$; $\bullet$, Station F $(0.51) ;+$, Station E (0.72); $\bullet$, Station C (0.22); A, Station K $(x \cdot 22)$. 
Different samples taken at the same station in the course of the day sometimes exhibited different types of uptake. At Station C (Figure 3), the monophasic uptake observed in the morning was followed by biphasic uptake in the afternoon. The uptake rates $l$ and $d$ for some stations are shown Figure 4, together with the incident light.

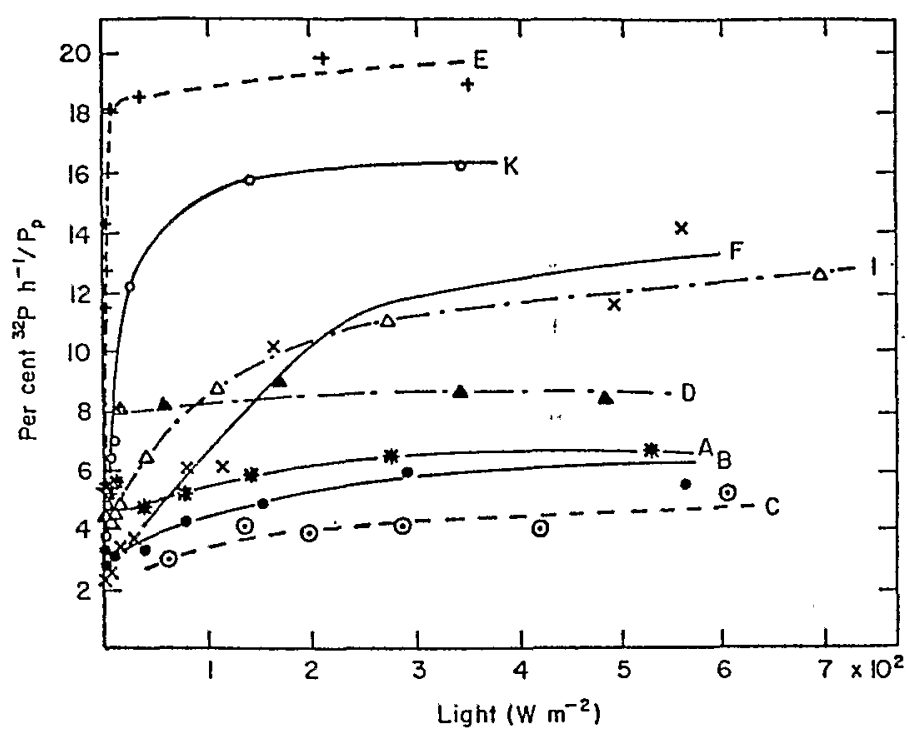

Figure 6. Phosphate uptake rate, in per cent of initial activity, vs. light intensity averaged on the whole incubation period. 'Vertical' incubations with surface water samples. Symbols (with in situ $\mathrm{PO},-\mathrm{P}$ in $\left.\mu \mathrm{mol}^{-1}\right)$ : *, Station A $(0.33)$; Station B $(0 \cdot 48) ; \odot$, Station C $(0 \cdot 20) ; \Lambda$, Station D (0.09); +, Station E (0.72); $X$, Station F (0.5I); $\Delta$, Station I (d) (0.4I); O, Station K (0.57).

\section{Influence of light}

Various stations frequently showed a difference between $l$ and $d$ incubations during either the whole day or only a part of it. From the variations of uptake rates during the day in relation with incident light, we may make a three groups classification:

(a) Stations I, E, K: $l$ uptake is very different from $d$ uptake and follows the light variations.

(b) Stations B, C, F: Uptake is stimulated by light, but does not exactly follow its variations.

(c) Stations A, D: $l$ Uptake is equal to $d$ uptake all the day, at least as determined from the 'stepwise' incubations.

A strong correlation between incident irradiance and $(l-d)$ uptake appears during the 'stepwise' incubations (Figure 5) for the first set of stations. This relationship is confirmed : by the 'vertical' incubations, during which the water temperature is uniform along the water column. At low light levels, all curves of $l$ uptake $v$ s. averaged irradiance converge to a mean uptake rate of $0.04 \mathrm{~h}^{-1} \mathrm{P}_{\mathrm{p}^{-1}}$ (between 0.02 and 0.05) (Figure 6) which represents the dark uptake and the adsorption. At higher light levels we observed a saturation-type response, the maximum being reached at various intensities which were very low in the case of Station E. 
We have seen (Figure 4 ) that Station $A$ shows no difference between $l$ uptake and $d$ uptake as determined by 'stepwise' $2-\mathrm{h}$ incubations. Figures of a longer 'vertical' incubation where an expanded scale for depth was used (Figure 8), show a decreasing uptake rate under decreasing light intensity.

The only case of photo-inhibition appears at Station B on 4 May 1976 (Figure 7 ) when the experiment was of the 'vertical' type with incubations carried out at sampling levels. A maximum uptake was reached around $400 \mathrm{~W} \mathrm{~m}^{-2}$ (irradiance averaged for the incubation period). The weather was exceptionally clear and at the other stations, the light levels were probably too low for such an inhibition to occur.

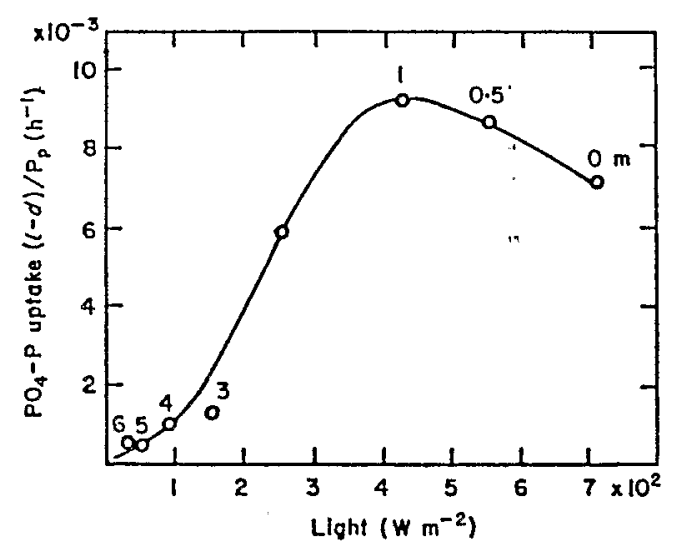

Figure 7. Phosphate uptake rate $v$ s. light intensity at Station B. 'Vertical' incubation, light intensity averaged on the incubation period; the uptake rate is the difference $(l-d)$ divided by particulate $P$. An inhibition by light appears to take place above $400 \mathrm{~W} \mathrm{~m}^{-2}$.

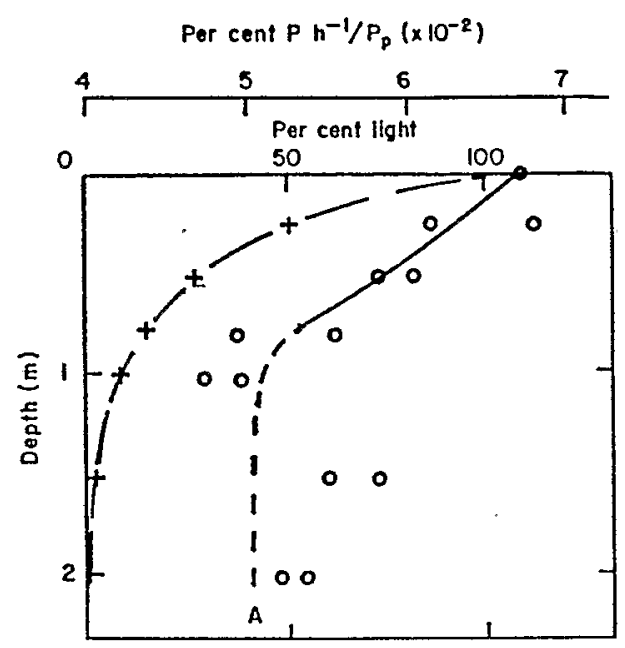

Figure 8. Phosphate uptake rate and incident light vs. depth at Station A. 'Vertical' incubation with surface water uptake rate in per cent of initial activity (solid line), light intensity in per cent of surface intensity (dashed line). The uptake rate. decreases slowly with decreasing light; the in situ PO,-P concentration is low $\left(0.14 \mu \mathrm{mol} \mathrm{I}^{-1}\right)$. 
TABLE 3. Half-saturation constants $\left(K_{\mathrm{s}}\right)$ and maximum uptake rates $\left(V_{\mathrm{ma}}\right)$ for orthophosphate; chl $a$ in $\mu \mathrm{g}^{-1}$

\begin{tabular}{|c|c|c|c|c|c|c|c|c|c|}
\hline \multirow[b]{2}{*}{ Station } & \multirow[b]{2}{*}{ Date } & \multirow[b]{2}{*}{ Time (h) } & \multicolumn{2}{|c|}{$V_{\mathrm{m}}$} & \multicolumn{2}{|c|}{$K_{s}$} & \multirow[b]{2}{*}{$\begin{array}{l}V_{m} / P_{p} \\
\left(h^{-1}\right)\end{array}$} & \multirow[b]{2}{*}{$\begin{array}{c}\mathrm{PO}_{1}-\mathrm{P} \\
\underset{1-1}{\mu \mathrm{mol}}\end{array}$} & \multirow[b]{2}{*}{$\begin{array}{l}V_{\mathrm{m}} / \mathrm{chl} a \\
\left(\times 10^{-3}\right)\end{array}$} \\
\hline & & & $\underset{\left.1^{-2} h^{-1}\right)}{(\mu \mathrm{mol}}$ & S.E. & $\underset{\left.1^{-1}\right)}{(\mu \mathrm{mol}}$ & s.z. & & & \\
\hline \multirow[t]{3}{*}{ A } & I $\mathrm{Jan} \times 977$ & 9.20 & 3.35 & 0.19 & 2.99 & 0.47 & $2 \cdot 4 I$ & 0.07 & 135 \\
\hline & & $\Upsilon 6.55$ & 2.99 & 0.14 & $2 \cdot 59$ & 0.34 & $2 \cdot 04$ & 0.07 & 102 \\
\hline & & 23.15 & 2.99 & 0.16 & $2 \cdot 6 x$ & 0.37 & I.94 & 0.09 & 100 \\
\hline \multirow[t]{2}{*}{ B } & I Feb $\times 977$ & 10.20 & 0.040 & 0.004 & 0.42 & $0 \cdot 13$ & 0.03 & 0.40 & $2 \cdot 8$ \\
\hline & & 21.09 & 0.036 & 0.003 & 0.37 & 0.14 & 0.03 & 0.33 & $2 \cdot 3$ \\
\hline \multirow[t]{2}{*}{ C } & I5 Feb 1977 & 10.17 & 0.39 & 0.04 & $4 \cdot 17$ & $0.9 x$ & 0.48 & 0.18 & $60 \cdot 4$ \\
\hline & & $22.1 x$ & 0.16 & 0.03 & $2 \cdot 37$ & $x \cdot 00$ & 0.17 & 0.15 & $25 \cdot 2$ \\
\hline \multirow[t]{2}{*}{$\mathrm{D}$} & 22 Feb $x 977$ & 10.38 & 0.29 & 0.02 & 0.25 & 0.06 & 0.21 & 0.12 & $25 \cdot 2$ \\
\hline & & 19.30 & 0.29 & $0.0 x$ & 0.29 & 0.04 & 0.22 & 0.14 & $20 \cdot 2$ \\
\hline \multirow{2}{*}{$\mathrm{E}$} & 18 Jan 1977 & 14.15 & 0.155 & 0.002 & 0.25 & 0.01 & 0.13 & 0.46 & $16 \cdot 0$ \\
\hline & & 19.19 & $0.08 \mathrm{I}$ & 0.005 & 0.46 & 0.21 & 0.09 & 0.75 & $5 \cdot 7$ \\
\hline $\mathrm{F}$ & 8 Feb 1977 & 10.15 & 0092 & 0.008 & 3.32 & 0.58 & 0.16 & 0.47 & $14 \cdot 2$ \\
\hline \multirow[t]{2}{*}{ I } & 4. Jan 1977 & $r 6.02$ & 0.145 & 0.008 & $x \cdot 44$ & 0.30 & 0.10 & $2 \cdot 66$ & $8 \cdot 4$ \\
\hline & & 22.10 & 0.15 & 0.02 & $3 \cdot 15$ & $I \cdot 2 \mathrm{I}$ & O.IX & $3 \cdot 04$ & $7 \cdot 8$ \\
\hline \multirow[t]{2}{*}{$\mathrm{K}$} & 25 Jan 1977 & 10.40 & $0 \cdot 160$ & 0.004 & 0.12 & 0.05 & 0.24 & 0.57 & $17 \cdot 0$ \\
\hline & & 20.40 & 0.10 & 0.02 & 0.62 & $I \cdot 06$ & 0.15 & 0.87 & $9 \cdot 3$ \\
\hline
\end{tabular}

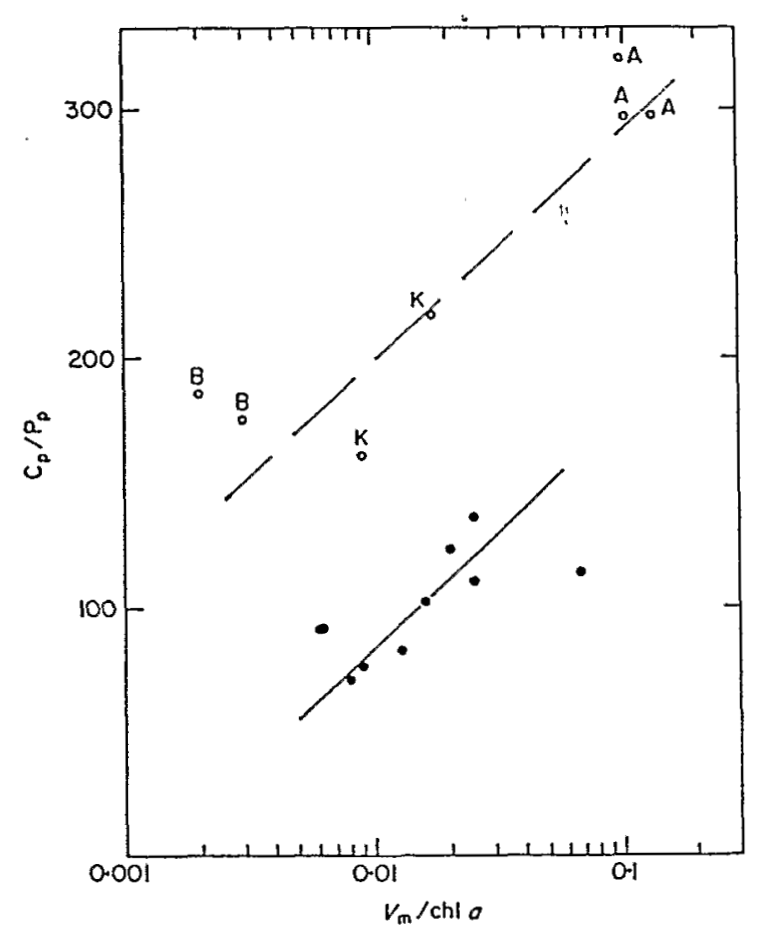

Figure 9. Relative maximum uptake velocity $\left(V_{\mathrm{m}} / \mathrm{chl} a\right)$ vs. $\mathrm{C}_{\mathrm{p}} / \mathrm{P}_{\mathrm{p}}$ seston ratio. The two groups of stations reflect a different composition of seston in the nearly freshwater stations ( $A, B$ and $K$ ) and the brackish stations. All values averaged over $24 \mathrm{~h}$. 


\section{Uptake kinetics (Table 3)}

The kinetic constants $V_{\mathrm{m}}$ (maximum uptake rate) and $K_{\mathrm{s}}$ (half-saturation substrate concentration) enable us to appreciate ise degree of adaptation of the populations to their surroundings, particularly to low PO, $\mathrm{P}$ concentrations. Perry (1976) has shown that $V_{\mathrm{m}}$ is higher when $\mathrm{P}$ deficiency is more pronounced as is the case at Station $\mathrm{A}$, where $V_{\mathrm{m}}$ is high. $K_{\mathrm{s}}$ is much higher $\left(2 \cdot 6 \mu \mathrm{mol}^{-1}\right)$ than the in situ $\mathrm{PO}_{4}-\mathrm{P}$ concentration (around $0.07 \mu \mathrm{mol} 1^{-1}$ ) which suggests that the phytoplankton population could not utilize orthophosphate efficiently' at such low concentrations.

If we plot the maximum uptake rate per unit pigment $\left(V_{\mathrm{m}} / \mathrm{chl} a\right)$ against the particulate $C_{p} / P_{p}$ atomic ratio (Figure 9 ) we see that the three Stations $A, B$ and $K$ stand aside. At these stations, with salinity near zero, the specific composition of phytoplankton was different, from that of the other stations-(Maurer, 1978).

\section{Discussion}

Mono- and biphasic uptake

The adsorption processes are insensitive to light, and last a few minutes; they are analogous to the processes observed by Sebetich (1975) for inert particles, and could represent equilibrating exchange processes between the medium and the particles after addition of ${ }^{32} \mathrm{P}$. 'The first phase in the biphasic type is also marked by a high uptake rate which has been attributed to bacteria (Rigler, 1956). This assumption may be good in some cases, since Fuhs et al. (1972) and Rhee (1972) have shown that bacteria compete with phytoplankton for phosphorus at external $\mathrm{PO}_{4}-\mathrm{P}$ concentrations lower than $0^{\circ} 5 \mu \mathrm{mol}^{-1}$, as would be the case for biphasic Stations $A$ and $D$ (daily average 0.14 and $0.13 \mu \mathrm{mol}^{-1}$ respectivcly). This involvement of the bacteria is probably not the only explanation and the concentration of particulate matter may also play a rôle in the adsorption processes, as seen experimentally by Sebetich (1975).

This first phase of the diphasic type could be an exchange and not a true uptake, the absorption mode being infuenced by the phosphorus depletion. When the extracellular phosphorus was low, the exchange would be limited to the cellular membrane (Taft et al., 1975) without reaching the intracellular pool. Our data support this hypothesis: the rapid uptake phase is particularly important at phosphorus depleted stations where the microbial populations rapidly take up $\mathrm{PO}_{4}-\mathrm{P}$. The uptake rate would increase in cells which have been starved for a longer time (Lehman, 1976), as is the case at Station $\mathrm{A}$ where the $\mathrm{PO}_{4}-\mathrm{P}$ concentration was lower than $0.15 \mu \mathrm{mol} 1^{-1}$ during all the year round, and where the $C_{p} / P_{p}$ atomic ratio was 312 (instead of 178 and 129 at Stations $B$ and $D$ respectively). This $P$ depletion, combined with an $N$ depletion at Stations $A$ and $D\left(C_{p} / N_{p}\right.$ atomic ratio : $x 0_{5}$ and 10.8 respectively) caused a marked adsorption phase, which was particularly high at Station A.

The second phase of the actual uptake was not always linear with time and with a simulation model of tracer uptake experiment (Pagès \& Lemasson, 1978), it can be seen that the second part of the second phase corresponds to the onset of tracer excretion. Rigler (1973) suggested that $\mathrm{PO}_{4}-\mathrm{P}$ uptake kinetics were following a two compartment exchange model; but with a six compartment model (Pagès \& Lemasson, 1978) it is possible to take adsorption and excretion into account, and, in the case of Ebric lagoon this model is a good approach of the phosphorus kinetics. Indeed Lean \& Rigler (1974) and Lean \& Nalewajko (1976) observed that the phosphorus exchange between seston and external pool of phosphate was the main phosphorus flux, and a two compartment model is inadequate if excretion is ignored. 
Organic and inorganic excretion would bring about the decrease of uptake rate in the second phase (diphasic uptake) and at the end of the uptake phase (monophasic uptakc). 'I'his excretion is about $8.5 \%$ for organic $\mathrm{P}$ and $17 \%$ for inorganic $\mathrm{P}$ (in $\mathrm{h}^{-1}$ of the biomass cvaluated by $P_{p} h^{-1}$ (Lemasson \& Pagès, in preparation).

\section{Circadian cycle and light influence}

A 24-h rhythm in phosphate uptake was observed with higher uptake in the early morning for nearly all the stations and later for Stations $\mathrm{I}$ and $\mathrm{K}$ and lowest uptake is in late afternoon. These results agree with those of Stross \& Pemrick (1974) and Eppley ct al. (197x) who observed in cultures a higher $\mathrm{P}$ uptake in the morning. The coincidence between phosphate uptake rhytimm and photosynthesis or light rhythm (as observed at Stations I, E and K), was also observed by Chisholm \& Stross (1976) in P-depleted cultures of Euglena gracilis. Uptake rates $l$ and $d$ arc different for most of the stations, but Taft (1974), Tuft et al. (r975) in the Chesapeake bay, and Perry ( 1976 ) in the Central Nörth Pacific did not observe different $l$ and $d$ uptake. Healey (x973) suggested that a difference can occur but only at unrealistically high dissolved phosphate concentrations. Faust \& Corell (1976) found identical light and dark uptakes and interpreted this as an uptake of orthophosphate principally by heterotrophic organisms. Little, if any difference between $l$ and $d$ uptake is exhibited by Stations $A$ and $D$, which have been shown to be strongly depleted and to have identical biphasic $l$ and $d$ uptakes (Figures 4 and 6). These obscrvations agree with those of Chisholm \& Stross (r976), and Fuhs et al. $\left(x_{972}\right)$ on P-limited diatons which do not reduce their uptake rate in the dark.

In the Ebrié Lagoon, light would be a stimulant for phosphate uptake, but the maximum value of phosphate uptake rate seems to have been independent of light intensity when light energy was higher than a limit value (for Station $F$ it is $200 \mathrm{~W} \mathrm{~m}^{-2}$ ). The $(l-d)$ uptake corresponds to a supplementary $\mathrm{P}$ uptake, which could represent two possible, and not mutually exclusive, processes: either reserves synthesis (polyphosphates) and concordance with the RNA synthesis, or relation with photophosphorylation related with energetic requirements of photosynthesis. In the latter case, photophosphorylation and photosynthesis would not be in phase since photophosphorylation is independent from $\mathrm{CO}_{2}$ uptake.

Phytoplankton at Station $\mathrm{F}$ shows a peculiar behaviour, as the $l$ uptake decreases and becomes identical to the $d$ uptake at noon, but no obvious $P$ depletion exists $\left(C_{p} / P_{p}\right.$ less than the classical $106 / \mathrm{r}$ at : at (Redficld et al., 1963 ) and $0.5 \mu \mathrm{mol}^{-1} \mathrm{PO}_{4}-\mathrm{P}$ in situ concentration). However both $\mathrm{P}$ uptake and $\mathrm{C}$ uptake daily values were lower than at other stations $\left(0^{\circ} 4 \mathrm{x}\right.$ and $39 \mathrm{mmol}^{-1}$ respectively) when photosynthesis was limited by an $\mathrm{N}$ depletion observed in the estuary region (Dufour et al., 1980). Mioreover, the diminution of $\mathrm{P}$ uptake during the day would be dependent upon the diminution of the photosynthesis in an Ndepleted medium. This decrease of photosynthesis following $N$ depletion is well documented

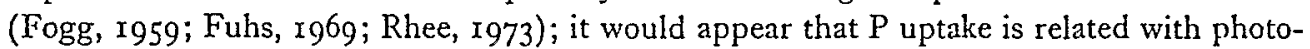
synthesis, either through a causative link or as a direct consequence of a $\mathrm{N}$ depletion.

Since we worked under natural, and hence variable, light the vertical profiles of uptake do not lend themselves to a determination of a critical light intensity analogous to the $I_{\mathbf{k}}$ value defined for photosynthesis (Talling, 1957). We can therefore only take a light intensity averaged across the incubation period into account.

\section{Luxury uptake and assimilation ratios}

Luxury uptake, exceeding the actual needs of the cell, has been shown to occur for $\mathrm{C}$ and $\mathrm{P}$ (Caperon, r968; Krupatkina, x97x; Rhee, 1973; Droop, x974; Lean \& Nalewajko, x976). 
Lehman (1976) suggests that luxury uptake of carbon, increasing the stored carbohydrates (Fogg, x965; Fuhs et al., 1972), causes both a sinking of the heavier cells towards P-rich layers where they can survive upon their $\mathrm{C}$ rescrves, and an increase in membrane surface allowing a higher absolute uptake per cell. If these cells are afterwards transferred into the cutrophic zone they are later able to grow again.

The uptake ratio $\Delta \mathrm{C} / \Delta \mathrm{P}$ enables us to evaluate the probable evolution of the constitution ratio $\mathrm{C}_{\mathrm{p}} / \mathrm{P}_{\mathrm{p}}$. The $\mathrm{P}$-depleted westernmost part of the lagoon (Station $\mathrm{A}$ ) shows a marked luxury $C$ uptake, with a $C_{p} / N_{p} / P_{p}$ ratio of $297 / 32 / r$ (at : at) rising in $24 \mathrm{~h}$ to $348 / 30 / \mathrm{r}$. The $\Delta \mathrm{C} / \Delta \mathrm{P}$ ratio was 549 on a $24 \mathrm{~h}$ basis, and the uptake rate was around $0.035 \mathrm{~h}^{-1}$ (relative to $P_{p}$ ) until noon, after which it decreased (Figure 4) to $0.015^{h^{-1}}$ at $22.00 \mathrm{~h}$ (local time). This decrease was probably due to nutrient depletion, as the in situ concentrations sink steadily from 0.30 to $0.04 \mu \mathrm{moll}^{-1} \mathrm{PO}_{4}-\mathrm{P}$ between 08.00 and $06.00 \mathrm{~h}$ the next morning. The replenishment of the nutrients seems to depend on the wind conditions, since in these very shallow waters (less than $2 \mathrm{~m}$ ), the surface and bottom layers can be easily mixed, and the bottom particulate matter and sediments are readily resuspended. When the wind abates, the surface layer becomes rapidly depleted, leading to strong nutrient gradients $\left(x \mu \mathrm{mol} 1^{-1}\right.$ $\mathrm{m}^{-1} \mathrm{PO}_{4}-\mathrm{P}$ in January and April, $\mathrm{r} 976$ ).

The marked imbalance of the ratio $\Delta \mathrm{C} / \Delta \mathrm{P}$ at this station seems to stem from an excessive $\triangle \mathrm{C}$ owing to a luxury $\mathrm{C}$ uptake in P-deficient cells; $\Sigma \mathrm{P}$ and ATP are low, but the ratio $\Sigma \mathrm{P} / \mathrm{ATP}$ is $\mathrm{I} \cdot 77\left(\mu \mathrm{mol} \mathrm{P}(\mu \mathrm{g} \mathrm{ATP})^{-1}\right.$ day $\left.^{-1}\right)$ which is a reasonable value compared to that of the others stations (Table 2). The low ATP concentration $\left(0.32 \mu \mathrm{g}^{-1}\right)$ reflects, in the deficient cells, an equilibrium with cellular $\mathrm{P}$ and reflects the nutrient depletion too (Sakshaug \& Holm-Hansen, r977). A luxury $C$ uptake is also found at Station $B$, with a $C_{p} / P_{p}$ rising from $I 6 \mathrm{I}$ to $\mathrm{I} 85$ over $24 \mathrm{~h}$ and a $\Delta \mathrm{C} / \Delta \mathrm{P}$ ratio of 270 , but the Chl $a$ concentration does not rise. The in situ $\mathrm{PO}_{4}-\mathrm{P}$ concentrations were around $0.40 \mu \mathrm{mol} 1^{-1}$ and seem to be high enough compared with the $K_{s}$ values $\left(0.37\right.$ to $\left.0.42 \mu \mathrm{mol} 1^{-1} \mathrm{PO}_{4}-\mathrm{P}\right)$. These observations indicate that $P$ is not the limiting factor which slows down chlorophyll production and $\mathrm{P}$ uptake. Indeed Dufour et al. (I980) have shown that nitrogen is the first limiting factor at this station. In contrast to these two examples of luxury $C$ uptake at nutrient depleted stations, we observed a luxury $\mathrm{P}$ uptake at estuarine stations where an occasional $\mathrm{P}$ excess occurs.

\section{Acknowledgements}

We thank J. F. Bois for his support and for use of facilities in his laboratory (Laboratoire des Radioisotopes, sponsored by C. E. A.), and Captain R. Tanter for his assistance during the various cruises on board the $A k w e$. This research was partly subsidized by B. S. I. E. funds of Ivory Coast.

\section{References}

Caperon, J. C. I 968 Population growth response of Isochrysis galbana to nitrate variations at limiting concentrations. Ecology 49, 866-872.

Chisholm, S. W. \& Stross, R. G. 1976 Phosphate uptake kinetics in Euglena gracilis (z) (Euglenophyceae) grown in light/dark cycles. Ir. Phased $\mathrm{PO}_{4}$-limited cultures. Fournal of Phycology $12,217-222$.

Droop, M. R. 1974 The nutrient status of algal cells in continuous culture. Fournal of the Marine Biological Association of the United Kingdom 54, 825-855.

Dufour, Ph., Lemasson, L. \& Cremoux, J. L. I 980 Contrôle nutritif de la biomasse du seston dans une lagune tropicale de Côte d'Ivoire. II. Variations géographiques saisonnières. Fournal of Experimental Marine Biology and Ecology. (Submitted). 
Eppley, R. W., Carlucci, A. F., Holm-Hansen, O., Kiefer, D., McCarthy, J. J., Venrick, E. \& Williams, P. M. $\times 97 \times$ Phytoplankton growth and composition in shipboard cultures supplied with nitrate, ammonium or urea as the $\mathrm{N}$ source. Limnology and Oceanography $16,74 \mathrm{x}-75 \mathrm{I}$.

Faust, M. A. \& Correll, D. L. I 976 Comparison of bacterial and algal utilization of orthophosphate in an estuarine environment. Marine Biology 34, I $51-162$.

Fogg, G. E. r 959 N nutrition and metabolic patterns in algae. Symposium of the Society for Experimental Biology 13, 106-x 25 .

Fogg, G. E. x965 Algal Cultures and Phytoplankton Ecology. University of Wisconsin Press, Madison, $126 \mathrm{pp}$.

Fuhs, G. W. $x_{969} \mathrm{P}$ content and rate of growth in the diatom Cyclotella nana and Thalossiosira fluviatilis. Fournal of Phycology 5, 305-32x.

Fuhs, G. W., Demerle, S. E., Canelli, E. \& Chen, M. 1972 Characterisation of phosphate-limited plankton algae. In Nutrients and Eutrophication: The Limiting Nutrient Controversy. Symposium of the American Society for Limnology and Oceanography, Vol. x, Allen Press, Inc., pp. $1 \times 3^{-1} 33$.

Healey, F. 1973 Inorganic nutrient uptake and deficiency in algae. Critical Review of Microbiology 3, $69-1 \times 3$.

Holm-Hansen, O. \& Booth, C. I 966 The measurement of ATP in the Ocean and its ecological significance. Limnology and Oceanography xI, $510-519$.

Kobayashi, Y. \& Maudsley, D. 1974 Biological Applications of Liquid Scintillation Counting. Academic Press, New York, I96 pp.

Krupatkina, D. x97 $\mathrm{P}$ uptake by planktonic algae in the dark and under faint light. Oceanology II, $22 \mathrm{I}-226$.

Lean, D. R. $x 973$ Movement of $P$ between its biologically important forms in lake water. fournal of the Fisheries Research Board of Canada 30, I 525-1 536.

Lean, D. R. \& Rigler, F. H. I974 A test of the hypothesis that abiotic phosphate complexing influences phosphorus kinetics in epilimnetic lake water. Limnology and Oceanography $19,784-788$.

Lean, D. R. \& Nalewajko, C. 1976 . Phosphate exchange and organic P excretion by freshwater algae. Fournal of the Fisheries Research Board of Canada 33, $1312-1323$.

Lehman, J. 1976 Photosynthetic capacity and luxury uptake of $\mathrm{C}$ during phosphate limitation in Pediastrum duplex (Chlorophyceae). Fournal of Phycology 12, 190-193.

Lemasson, L. \& Pagès, J. Note on the excretion of dissolved organic phosphorus in tropical brackish water (In preparation).

Lemasson, L., Pagès, J., Dufour, Ph. \& Cremoux, J. L. 1980 Matière organique particulaire et biomasse dans une lagune tropicale. Cahiers ORSTOM, série Océanographie (in press).

Mackereth, F. J. 1953 P utilization by Asterionella formosa. Fournal of Experimental Botany 4, 296.

Maurer, D. 1978 Phytoplancton et pollution. La lagune Ebrié (Abidjan). Le secteur de Cortiou (Marseille). Thèse doctorat $3^{e}$ cycle. Université d'Aix-Marseille, I2I pp.

Moal, J., Samain, S. \& Lccoz, J. 1977 C/N et contrôle de la physiologie des cultures de phytoplankton. Accepted for publication in the Proceedings of the 12 th European Marine Biology Symposium, Stirling.

Pagès, J. \& Lemasson, L. 1978 Note sur l'utilisation des traceurs radioactifs en écologie aquatique. Publications Scientifiques et Techniques du Centre National pour l'Exploitation des Océans: Actes de Colloques $\mathrm{n}^{\circ} .7,747 \mathrm{pp}$.

Pagès, J., Lemasson, L. \& Dufour, Ph. r980 Primary production measurements in a brackish tropical lagoon. II: Effect of light, as studied at some stations by the ${ }^{14} \mathrm{C}$ method. Cahiers ORSTOM, série Hydrobiologie (in press).

Perry, M. J. 1976 Phosphate utilization by an oceanic diatom in P-limited chemostat culture and in the oligotrophic waters of the Central North Pacific. Lintrology and Oceanography 21, 88-107.

Redfield, A. C., Ketchum, B. H. \& Richards, F. A. I 963 The influence of organisms on the composition of sea water. In The Sea, Volume 2 (Hill, M. N., ed.). Interscience, 26-77.

Rhee, G. Y. 1972 Competition between analga and an aquatic bacterium for phosphate. Limnology and Oceanography $17,505-514$.

Rhee, G. Y. 1973 A continuous culture study of phosphate uptake, growth rate and poly phosphate in Scenedesmus sp. Foutrnal of Phycology 9, 495-506.

Rigler, F. H. 1956 A tracer study of the P cycle in lake water. Ecology 37, 550-562.

Rigler, F. H. r 973 A dynamic view of phosphorus cycle in lakes. In Environmental phosphorus handbook (Griffith, E. et al. ed.). John Wiley and Sons, Inc., Toronto, Ontario, 539-572.

Sakshaug, E. \& Holm-Hansen, O. 1977 Chemical composition of Skeletonema costatum and Pavloz̃ă lutheri as a function of nitrate phosphate and iron-limited growth. Journal of Experimental Marine Biology and Ecology 29, $\mathrm{x}-34$.

Sebetich, M. J. 1975 P kinetics of freshwater microcosms. Ecology 56, 1262-1280.

Strickland, J. D. \& Parson, T. R. I968 A practical handbook of sea water analysis. Bulletin of the Fisheries Research Board of Canada $\mathrm{x67}, 3 \mathrm{II}$ pp. 
Stross, R. G. \& Pemrick, S. $x 974$ Nutrient uptake kinetics in phytoplankton: a basis for nich separation. fournal of Phycology xo, 164-169.

Taft, J. L. 1974 Phosphorus cycling in the plankton of Chesapeake Bay. Ph.D. Thesis, John Hopkins University, Baltimore, $193 \mathrm{pp}$.

Taft, J. L., Taylor, W. R. \& McCarthy, J. J. 1975 Uptake and release of P by phytoplankton in the Chesapeake Bay Estuary, USA. Marine Biology 33, $2 x-32$.

Talling, J. F. 1957 The phytoplankton population as a compound photosynthetic system. New Phytologist 56, $133-149$.

Tastet, J. 1974 L'environnement physique du système lagunaire Ebrié. Université d'Abidjan, séric Documents $\mathrm{I}, 27$ pp., 58 fig.

Varlet, F. 1978 Le régime de la lagune Ebrié. Travaux et Documents ORSTOM 83, x62 pp, r ro fig. Wilkinson, G. N. I96I Statistical estimations in enzyme kinetics. Biochentical Fournal 80, 324-332. 